\title{
Pengujian Black Box pada Aplikasi Verifikasi Data Nasabah dengan Menggunakan Metode Boundary Value Analysis
}

\author{
Lailan Cipta Hermawan¹, Moh. Rizki Mubarok², Hidayat Mairudin³, Ahmad Mahdiyan4, \\ Yulianti Yulianti ${ }^{5}$ \\ Teknik Informatika, Universitas Pamulang, Jl. Raya Puspitek No.46, Buaran, Serpong, Tangerang \\ Selatan, Banten, Indonesia, 15310 \\ e-mail: ${ }^{1}$ lailancipta@yahoo.co.id, ${ }^{2}$ rizkimubarok22@gmail.com, ${ }^{3}$ hidayatmairudin@gmail.com, \\ 4ahmadmahdiyan96@gmail.com, ${ }^{5}$ yulianti@unpam.ac.id
}

Submitted Date: June $02^{\text {nd }}, 2020$

Revised Date: July $31^{\text {st }}, 2020$
Reviewed Date: June $29^{\text {th }}, 2020$

Accepted Date: August $01^{\text {st }}, 2020$

\section{Abstract}

Testing is one level that must be passed in order to produce results from a weighted sistem. If no testing is done on the sistem, the quality of the sistem cannot be known so that if an error occurs it can harm the sistem. By conducting experiments can find the location of defects in a sistem that can be known from the beginning that can be fixed immediately. Testing there are several types of sistem experiments, experiments used are Black Box testing using a limit value analysis method that is effective in trying the functions of a sistem. Testing techniques by making test cases based on limits on lower and upper values can provide good coverage and represent the actual input values. Based on the results of tests conducted with the analysis of boundary values, the application developed has been error free. This gives a guarantee that the application developed has met the requirements and is of high quality.

\section{Keywords: Boundary Value Analysis; Online News; Black Box Testing}

\begin{abstract}
Abstrak
Pengujian adalah salah satu tingkatan di mana dan harus dilewati untuk menghasilkan sebuah sistem yang sangat berbobot dan bermanfaat. Karena jika tidak dilakukan pengujian terlebih dahulu pada sebuah sistem, maka sistem tersebut tidak dapat diketahui kualitas dan kapasitasnya sehingga apabila terjadi kesalahan dapat sangat merugikan sistem tersebut bahkan user pengguna sistem tersebut. Dengan melakukan pengujian bisa mencari di mana letak kecacatan atau kegagalan pada sebuah sistem yang bisa diketahui dari awal yang dapat segera diperbaiki. Pada pengujian sendiri ada beberapa jenis pengujian sistem, pengujian yang akan digunakan adalah pengujian kotak hitam dengan cara menggunakan metode analisis nilai batas yang sangat ampuh dalam melakukan pengujian fungsi dari sebuah sistem. Teknik pengujian dengan membuat uji kasus berdasarkan batasan pada nilai bawah dan atas dapat memberikan cakupan yang baik dan mewakili nilai masukan yang sebenarnya. Berdasarkan hasil pengujian yang dilakukan dengan teknik analisis nilai batas menunjukkan bahwa aplikasi yang dikembangkan telah bebas dari kesalahan. Hal ini memberikan jaminan bahwa aplikasi yang dikembangkan telah memenuhi persyaratan dan memiliki kualitas yang tinggi.
\end{abstract}

Kata Kunci : Analisis Nilai Batas; Verifikasi Data Nasabah; Pengujian Kotak Hitam

\section{Pendahuluan}

Pengujian sistem sangatlah penting di mana pengujian sangat mengacu kepada kualitas dari sebuah sistem yang akan digunakan. Pengujian sistem adalah sesuatu yang harus diperhatikan serta amat dibutuhkan guna meyakinkan sebuah kualitas pada sistem yang masih dalam tahap pembuatan ataupun yang sudah ada agar dapat beroperasi dan berfungsi dengan benar pada setiap fungsinya. Pengujian sistem/aplikasi bertujuan untuk memastikan bahwa sistem/aplikasi yang dihasilkan telah sesuai dengan persyaratan (requirement) dan layak untuk digunakan (Arwaz, Putra, Putra, Kusumawijaya, \& Saifudin, 2019). Pengujian 
sistem meski ada waktu tersendiri, kadang dilakukan bersamaan pada saat implementasi atau pengkodean. Pengujian dilakukan dengan mencoba sistem, guna untuk mencari kecacatan atau kekurangan yang bisa diketahui dari awal yang dapat segera diperbaiki saat itu juga.

Pengujian akan berada pada bagian tertentu atau spesifikasi dan persyaratan yang diinginkan karena pada pengujian ini menggunakan penggambaran eksternal perangkat lunak. Di dalamnya sudah termasuk spesifikasi, syarat dan desain untuk mendapatkan hasil uji kasus (test case) pengujian.

Untuk mengharapkan fungsionalitas berjalan dengan baik pada perangkat lunak, maka perangkat lunak harus diuji. Pengujian perangkat lunak bertujuan untuk mencari berapa banyak kesalahan yang terjadi di dalam perangkat lunak tersebut.

Metode pengujian Black Box adalah pengujian yang memverifikasi hasil eksekusi aplikasi berdasarkan masukan yang diberikan (data uji) untuk memastikan fungsional dari aplikasi sudah sesuai dengan persyaratan (requirement) (Febrian, Ramadhan, Faisal, \& Saifudin, 2020). Pengujian Black Box yang memiliki arti bahwa pengujian yang dilakukan hanya mengambil hasil eksekusi melalui data uji dan memeriksa fungsional dari perangkat lunak (Krismadi, et al., 2019).

Dari sekian banyak perusahaan, PT. Bank Permata TBK telah menggunakan perangkat lunak sebagai alat bantu pada call center dalam mendapatkan informasi data para nasabah khususnya nasabah prioritas. PT. Bank Permata TBK sudah mengimplementasikan Sistem verifikasi ini untuk mempermudah mendapatkan informasi semua informasi yang dibutuhkan oleh para call center nasabah kredit maupun konfensional. Persoalan pada Sistem tersbut adalah tidak boleh adanya downtime pada operational perbankan yang dapat mengakibatkan rusaknya eleksibilitas perusahaan tersebut. Melihat permasalahan tersebut, peneliti bermaksud untuk melakukan analisis terhadap Sistem Verifikasi Data Nasabah pada PT. Permata Bank TBK memakai pengujian kotak hitam dengan menggunakan metode analisis nilai batas, sehingga mendapatkan gambaran tentang kondisi penjaminan kualitas perangkat lunak pada PT. Permata Bank TBK.

Rencana pengujian yang digunakan dalam pengujian ini menggunakan pengujian skenario untuk menguji bagian-bagian (field) yang akan diujikan. Pengujian akan dilakukan dengan membuat uji kasus (test case) berdasarkan nilai masukan tiap komponen masukan dan keluaran yang diharapkan. Dilanjutkan dengan mengeksekusi tiap uji kasus (test case) dan mencatat hasilnya. Kemudian dilakukan evaluasi dan perbaikan untuk meningkatkan kualitas aplikasinya.

\section{Metodologi Penelitian}

\subsection{Pengujian Whitebox}

Pengujian White Box bisa dikatakan sebagai pengujian yang akan memperhitungkan mekanisme internal yang ada pada sebuah sistem atau komponen. Pengujian White Box merupakan pengujian perangkat lunak yang didasarkan pada alur eksekusi kode program, apakah keluaran yang dihasilkan sudah sesuai dengan masukan dan algoritmanya serta sesuai spesifikasi yang dibutuhkan (Cholifah, Yulianingsih, \& Sagita, 2018). Pengujian White Box didasarkan pada desain program secara prosedural, secara struktural, pengujian berbasis logika atau pengujian berbasis kode program (Irawan, 2017). Jalur dasar merupakan merupakan bagian dari pengujian White Box, di mana dalam proses pengujian perlu malakukan analisa jalur eksekusi dengan membuat flow graph berdasarkan kode program dan juga menghitung nilai kompleksitas siklomatiknya untuk menentukan jumlah pengujian yang harus dilakukan. Pengujian ini bertujuan untuk memverifikasi kebenaran struktur program yang dibuat dan kinerja program (Rahayuda \& Santiari, 2017).

Kata lain dari White Box Testing adalah structural testing, Glass Box Testing dan Clear Box Testing. Makna dari Clear Box dan Glass Box Testing. Dapat dilihat dari tanda-tanda bahwa kita mempunyai kejelasan penuh pada suatu kerja internal pada perangkat lunak terutama pada logika dan struktur kodenya.

\subsection{Pengujian Black Box}

Pengujian perangkat lunak yang memakai pengujian kotak hitam digunakan untuk mendapatkan kecacatan dan kekurangan di beberapa bagian, yaitu fungsi-fungsi yang salah atau hilang, kesalahan antarmuka, kesalahan dalam struktur data atau akses database eksternal, kesalahan performa, kesalahan dan terminasi (Agarwal, Tayal, \& Gupta, 2010).

Pengujian kotak hitam adalah rencana percobaan yang memperhatikan detail sistem serat aspek dari fungsinya, mengenali jenis-jenis kecacatan fungsi antarmuka, kecacatan di model 
data serta kecacatan di jalan masuk ke dalam asal data disimpan (Sukamto \& Shalahuddin, 2013). Pengujian skenario adalah salah satu dari pengujian kotak hitam yang merupakan percobaan yang bersifat wajar, dapat dipercaya serta dapat mendorong pemangku kepentingan untuk mempermudah dalam pengujian dan evaluasi (Simarmata, 2010).

\subsection{Pengujian Boundary Value Analysis}

Teknik analisis nilai batas sudah digunakan guna mencoba sistem Berita Online, didalam pecobaan mendapatkan kecacatan pada sistem ketika melaksanakan verifikasi data, maka dapat menimbulkan masalah dalam menyimpan basis data (Mustaqbal, Firdaus, \& Rahmadi, 2015). Implementasi pengujian Black Box terkini analisis batas nilai adalah metode yang efektif guna mendapatkan kecacatan serta kelemahan di dalam sistem Berita Online (Andriansyah, 2018).

Analisis nilai batas adalah bagian dari metode Black Box yang mengerjakan percobaan dalam batasan atas dan bawah dari sebuah nilai yang dimasukkan ke dalam sistem. Syarat prinsip yang mendasari dari analisis nilai batas (Zuriati, Widyawati, Sitanggang, \& Buowo, 2018), yaitu:

1. Analisis nilai batas menguji sebuah nilai yang berlaku pada batas bawah ataupun batas atas.

2. Analisis nilai batas adalah bagian dari pengujian kelas kesetaraan di mana cuma jumlah masukan yang diperhatikan, sedangkan analisis nilai batas juga nilai keluarannya diperhatikan.

Berikut merupakan spesifikasi pengujian kotak hitam menggunakan metode analisis nilai batas (Jaya, 2018):

1. Apabila situasi angka yang dimasukkan terdapat antara angka i serta $\mathrm{j}$, sehingga $\mathrm{i}-$ $1, \mathrm{i}, \mathrm{j}, \mathrm{i}+1$ akan menjadi contoh data yang akan dibuat.

2. Apabila situasi memakai sebanyak angka, maka lebih sedikit -1 , lebih sedikit, paling banyak, paling banyak +1 akan menjadi contoh data yang akan dibuat.

3. Laksanakan tahap 1 dan 2 guna prosedur keluaran.

4. Apabila data masukan sudah mencapai batasnya, maka pada batasan percobaan tersebut dibuat.

Pengujian dilakukan pada Form memasukkan Berita memakai pengujian kotak hitam dengan metode analisis nilai batas, berikut merupakan tampilan dari Output Data Nasabah.

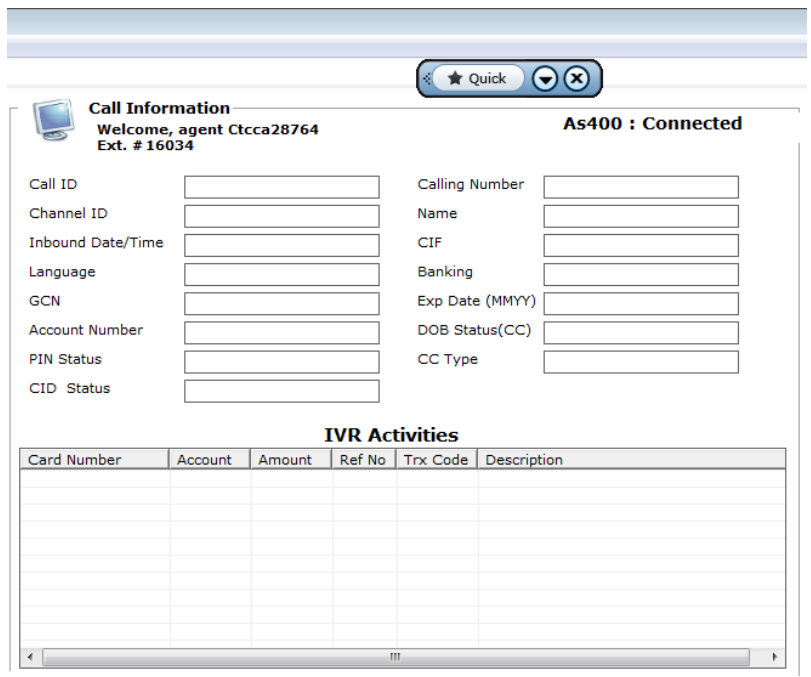

Gambar 1 Form Output Data Nasabah

Dialer

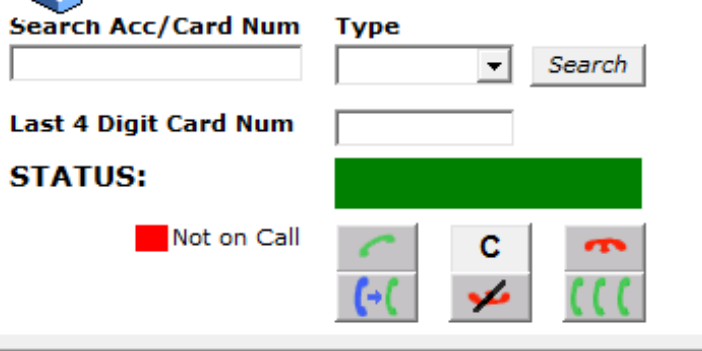

Gambar 2 Form Memasukkan No Kartu Nasabah

Tabel 1 Rancangan Pengujian

\begin{tabular}{|c|l|l|}
\hline $\begin{array}{c}\text { Test } \\
\text { ID }\end{array}$ & \multicolumn{1}{|c|}{ Deskripsi Pengujian } & \multicolumn{1}{c|}{ Hasil yang Diharapkan } \\
\hline C01 & $\begin{array}{l}\text { Pengujian dengan Nomor terdaftar } \\
\text { - Nasabah call ke Permata via IVR dan } \\
\text { tersambung ke agent dengan "nomor yang } \\
\text { terdaftar" }\end{array}$ & - CTI \& VB berhasil Pop Up \\
- Data Nasabah Muncul \\
\hline
\end{tabular}




\begin{tabular}{|c|c|c|}
\hline $\mathrm{CO2}$ & $\begin{array}{l}\text { Pengujian dengan no tidak terdafar } \\
\text { - Nasabah call ke Permata via IVR dan } \\
\text { tersambung ke agent dengan "nomor yang tidak } \\
\text { terdaftar" }\end{array}$ & $\begin{array}{l}\text { - CTI \& VB berhasil Pop Up } \\
\text { - Tampil Status No Match } \\
\text { - Hanya Muncul nomor yang digunakan untuk } \\
\text { menghubungi tanpa keluar data nasabah }\end{array}$ \\
\hline $\mathrm{C03}$ & $\begin{array}{l}\text { Pengujian dengan no tidak terdafar } \\
\text { - Nasabah call ke Permata via IVR dan } \\
\text { tersambung ke agent dengan "nomor yang tidak } \\
\text { terdaftar" } \\
\text { - Agent memasukkan "nomor kartu Debit dari } \\
\text { nasabah" }\end{array}$ & $\begin{array}{l}\text { - CTI \& VB berhasil Pop Up } \\
\text { - Hanya Muncul nomor yang digunakan untuk } \\
\text { menghubungi tanpa keluar data nasabah } \\
\text { - Saat memasukkan no kartu nasabah Data } \\
\text { nasabah muncul semua di form Data Nasabah }\end{array}$ \\
\hline C04 & $\begin{array}{l}\text { Pengujian dengan no tidak terdafar } \\
\text { - Nasabah call ke Permata via IVR dan } \\
\text { tersambung ke agent dengan "nomor yang tidak } \\
\text { terdaftar" } \\
\text { - Agent memasukkan nomor kartu Kredit dari } \\
\text { nasabah }\end{array}$ & $\begin{array}{l}\text { - CTI \& VB berhasil Pop Up } \\
\text { - Hanya Muncul nomor yang digunakan untuk } \\
\text { menghubungi tanpa keluar data nasabah } \\
\text { - Saat memasukkan no kartu nasabah Data } \\
\text { nasabah muncul semua di form Data Nasabah }\end{array}$ \\
\hline $\mathrm{C05}$ & $\begin{array}{l}\text { Pengujian dengan no tidak terdafar } \\
\text { - Nasabah call ke Permata via IVR dan } \\
\text { tersambung ke agent dengan "nomor yang tidak } \\
\text { terdaftar" } \\
\text { - Agent hanya memasukkan } 4 \text { digit terakhir dari } \\
\text { "nomor kartu Kredit dari nasabah" }\end{array}$ & $\begin{array}{l}\text { - CTI \& VB berhasil Pop Up } \\
\text { - Hanya Muncul nomor yang digunakan untuk } \\
\text { menghubungi tanpa keluar data nasabah } \\
\text { - Data nasabah muncul semua di form Data } \\
\text { Nasabah }\end{array}$ \\
\hline C06 & $\begin{array}{l}\text { Pengujian dengan no tidak terdafar } \\
\text { - Nasabah call ke Permata via IVR dan } \\
\text { tersambung ke agent dengan "nomor yang tidak } \\
\text { terdaftar" } \\
\text { - Agent hanya memasukkan } 4 \text { digit terakhir dari } \\
\text { "nomor kartu debit dari nasabah" }\end{array}$ & $\begin{array}{l}\text { - CTI \& VB berhasil Pop Up } \\
\text { - Hanya Muncul nomor yang digunakan untuk } \\
\text { menghubungi tanpa keluar data nasabah } \\
\text { - Data nasabah muncul semua di form Data } \\
\text { Nasabah }\end{array}$ \\
\hline
\end{tabular}

\section{Hasil dan Pembahasan}

Tahap selanjutnya dilaksanakan pengujian berdasarkan rancangan uji kasus (test case) yang telah dibuat. Hasil pengujian ditunjukkan pada Tabel 2

Tabel 2 Hasil Pengujian

\begin{tabular}{|c|c|c|c|c|}
\hline $\begin{array}{l}\text { Test } \\
\text { ID }\end{array}$ & Deskripsi Pengujian & Hasil yang Diharapkan & Hasil Pengujian & Status \\
\hline C01 & $\begin{array}{l}\text { Pengujian dengan Nomor } \\
\text { terdaftar } \\
\text { Nasabah call ke Permata via } \\
\text { IVR dan tersambung ke agent } \\
\text { dengan "nomor yang } \\
\text { terdaftar" }\end{array}$ & $\begin{array}{l}\text { - CTI \& VB berhasil Pop } \\
\text { Up } \\
\text { - Tampil Status Match } \\
\text { - Data Nasabah Muncul }\end{array}$ & $\begin{array}{l}\text { - CTI \& VB berhasil Pop } \\
\text { Up } \\
\text { - Tampil Status Match } \\
\text { - Data Nasabah Muncul }\end{array}$ & Ok \\
\hline C02 & $\begin{array}{l}\text { Pengujian dengan no tidak } \\
\text { terdafar } \\
\text { - Nasabah call ke Permata } \\
\text { via IVR dan tersambung ke } \\
\text { agent dengan "nomor yang } \\
\text { tidak terdaftar" }\end{array}$ & $\begin{array}{l}\text { - CTI \& VB berhasil Pop } \\
\text { Up } \\
\text { - Tampil Status No Match } \\
\text { - Hanya Muncul nomor } \\
\text { yang digunakan untuk } \\
\text { menghubungi tanpa } \\
\text { keluar data nasabah } \\
\end{array}$ & $\begin{array}{l}\text { - CTI \& VB berhasil Pop } \\
\text { Up } \\
\text { - Tampil Status No Match } \\
\text { - Hanya Muncul nomor } \\
\text { yang digunakan untuk } \\
\text { menghubungi tanpa } \\
\text { keluar data nasabah } \\
\end{array}$ & $\mathrm{Ok}$ \\
\hline $\mathbf{C 0 3}$ & $\begin{array}{l}\text { Pengujian dengan no tidak } \\
\text { terdafar } \\
\text { - Nasabah call ke Permata via } \\
\text { IVR dan tersambung ke } \\
\text { agent dengan "nomor yang } \\
\text { tidak terdaftar" }\end{array}$ & $\begin{array}{l}\text { - CTI \& VB berhasil Pop } \\
\text { Up } \\
\text { - Hanya Muncul nomor } \\
\text { yang digunakan untuk } \\
\text { menghubungi } \\
\text { keluar data nasabah }\end{array}$ & $\begin{array}{l}\text { - CTI \& VB berhasil Pop } \\
\text { Up } \\
\text { - Hanya Muncul nomor } \\
\text { yang digunakan untuk } \\
\text { menghubungi tanpa } \\
\text { keluar data nasabah }\end{array}$ & Ok \\
\hline
\end{tabular}




\begin{tabular}{|c|c|c|c|c|}
\hline & $\begin{array}{l}\text { - Agent memasukkan "nomor } \\
\text { kartu Debit dari nasabah" }\end{array}$ & $\begin{array}{l}\text { - Saat memasukkan no } \\
\text { kartu nasabah Data } \\
\text { nasabah muncul semua di } \\
\text { form Data Nasabah }\end{array}$ & $\begin{array}{l}\text { - Saat memasukkan no } \\
\text { kartu nasabah Data } \\
\text { nasabah muncul semua } \\
\text { di form Data Nasabah }\end{array}$ & \\
\hline $\mathrm{C04}$ & $\begin{array}{l}\text { Pengujian dengan no tidak } \\
\text { terdafar } \\
\text { - Nasabah call ke Permata via } \\
\text { IVR dan tersambung ke } \\
\text { agent dengan "nomor yang } \\
\text { tidak terdaftar" } \\
\text { - Agent memasukkan nomor } \\
\text { kartu Kredit dari nasabah }\end{array}$ & $\begin{array}{l}\text { - CTI \& VB berhasil Pop } \\
\text { Up } \\
\text { - Hanya Muncul nomor } \\
\text { yang digunakan untuk } \\
\text { menghubungi tanpa } \\
\text { keluar data nasabah } \\
\text { - Saat memasukkan no } \\
\text { kartu nasabah Data } \\
\text { nasabah muncul semua di } \\
\text { form Data Nasabah }\end{array}$ & $\begin{array}{l}\text { - CTI \& VB berhasil Pop } \\
\text { Up } \\
\text { - Hanya Muncul nomor } \\
\text { yang digunakan untuk } \\
\text { menghubungi tanpa } \\
\text { keluar data nasabah } \\
\text { - Saat memasukkan no } \\
\text { kartu nasabah Data } \\
\text { nasabah muncul semua } \\
\text { di form Data Nasabah }\end{array}$ & Ok \\
\hline C05 & $\begin{array}{l}\text { Pengujian dengan no tidak } \\
\text { terdafar } \\
\text { - Nasabah call ke Permata via } \\
\text { IVR dan tersambung ke } \\
\text { agent dengan "nomor yang } \\
\text { tidak terdaftar" } \\
\text { - Agent hanya memasukkan } 4 \\
\text { digit terakhir dari "nomor } \\
\text { kartu Kredit dari nasabah" }\end{array}$ & $\begin{array}{l}\text { - CTI \& VB berhasil Pop } \\
\text { Up } \\
\text { - Hanya Muncul nomor } \\
\text { yang digunakan untuk } \\
\text { menghubungi tanpa } \\
\text { keluar data nasabah } \\
\text { - Data nasabah muncul } \\
\text { semua di form Data } \\
\text { Nasabah }\end{array}$ & $\begin{array}{l}\text { - CTI \& VB berhasil Pop } \\
\text { Up } \\
\text { - Hanya Muncul nomor } \\
\text { yang digunakan untuk } \\
\text { menghubungi tanpa } \\
\text { keluar data nasabah } \\
\text { - Data nasabah muncul } \\
\text { semua di form Data } \\
\text { Nasabah setelah } \\
\text { memasukkan } 4 \text { digit } \\
\text { terakhir dari nomor } \\
\text { kartu Kredit dari } \\
\text { nasabah }\end{array}$ & Ok \\
\hline C06 & $\begin{array}{l}\text { Pengujian dengan no tidak } \\
\text { terdafar } \\
\text { - Nasabah call ke Permata via } \\
\text { IVR dan tersambung ke } \\
\text { agent dengan "nomor yang } \\
\text { tidak terdaftar" } \\
\text { - Agent hanya memasukkan } \\
4 \text { digit terakhir dari "nomor } \\
\text { kartu debit dari nasabah" }\end{array}$ & $\begin{array}{l}\text { - CTI \& VB berhasil Pop } \\
\text { Up } \\
\text { - Hanya Muncul nomor } \\
\text { yang digunakan untuk } \\
\text { menghubungi tanpa } \\
\text { keluar data nasabah } \\
\text { - Data nasabah muncul } \\
\text { semua di form Data } \\
\text { Nasabah }\end{array}$ & $\begin{array}{l}\text { - CTI \& VB berhasil Pop } \\
\text { Up } \\
\text { - Hanya Muncul nomor } \\
\text { yang digunakan untuk } \\
\text { menghubungi tanpa } \\
\text { keluar data nasabah } \\
\text { - Data nasabah muncul } \\
\text { semua di form Data } \\
\text { Nasabah setelah agent } \\
\text { memasukkan } 4 \text { digit } \\
\text { terakhir dari nomor } \\
\text { kartu debit dari nasabah }\end{array}$ & Ok \\
\hline
\end{tabular}

Pengujian Black Box menggunakan Boundary Value Analysis di atas dapat memberikan gambaran bagaimana serangkaian skenario diujikan untuk memperoleh nilai yang sebenarnya, sehingga ditemukan hasil pengujian dari 6 sekenario semua dapat dilakukan dengan baik tanpa ada kendala apapun sehingga hasil dari pengujian ini berjalan dengan lancar mencapai $100 \%$ pengujian dan bisa melanjutkan untuk menuju kelangkah berikutnya.

\section{Kesimpulan}

Berdasarkan hasil perolehan pengujian kotak hitam dengan menggunakan metode analisis nilai batas bisa disimpulkan bahwa:

1. Pengujian kotak hitam dengan menggunakan metode analisis nilai batas merupakan percobaan yang efektif guna mencari kesalahan pada fungsionalitas untuk menjamin data yang dimasukkan sesuai dengan fungsional yang diharapkan. Sebuah sistem, selain itu metode ini mudah untuk diimplementasikan karena hanya mengerjakan percobaan dalam batasan atas dan bawah dari sebuah angka di dalam sistem yang telah dimasukkan.

2. Melalui melihat format basis data, maka sketsa masukan sesuai dengan format data tersebut.

3. Pengujian fungsionalitas dilaksanakan menggunakan beberapa skenario masukan. 


\section{Referensi}

Agarwal, B. B., Tayal, S. P., \& Gupta, M. (2010). Software Engineering \& Testing. An Introduction. Sudbury, Massachusetts: Jones \& Bartlett Learning, LLC.

Andriansyah, D. (2018). Pengujian Kotak Hitam Boundary Value Analysis Pada Sistem Informasi Manajemen Konseling Tugas Akhir. Indonesian Journal on Networking and Security - Vol.7 No.1, 13-18.

Arwaz, A. A., Putra, K., Putra, R., Kusumawijaya, T., \& Saifudin, A. (2019). Pengujian Black Box pada Aplikasi Sistem Seleksi Pemenang Tender Menggunakan Teknik Equivalence Partitions. Jurnal Teknologi Sistem Informasi dan Aplikasi, 2(4), 130-134. doi:10.32493/jtsi.v2i4.3708

Cholifah, W. N., Yulianingsih, \& Sagita, S. M. (2018). Pengujian Black Box Testing pada Aplikasi Action \& Strategy Berbasis Android dengan Teknologi Phonegap. Jurnal String, 206-210.

Febrian, V., Ramadhan, M. R., Faisal, M., \& Saifudin, A. (2020). Pengujian pada Aplikasi Penggajian Pegawai dengan menggunakan Metode Blackbox. Jurnal Informatika Universitas Pamulang, 5(1), 61-66. doi:10.32493/informatika.v5i1.4340

Irawan, Y. (2017). Pengujian Sistem Informasi Pengelolaan Pelatihan Kerja UPT BLK Kabupaten Kudus. Sentra Penelitian Engineering dan Edukasi, 56-63.

Jaya, T. S. (2018). Pengujian Aplikasi dengan Metode Blackbox Testing Boundary Value Analysis
(Studi Kasus: Kantor Digital Politeknik Negeri Lampung). Jurnal Informatika: Jurnal Pengembangan IT, 3(1), 45-48. doi:10.30591/jpit.v3i1.647

Krismadi, A., Lestari, A. F., Pitriyah, A., Mardangga, I. W., Astuti, M., \& Saifudin, A. (2019). Pengujian Black Box berbasis Equivalence Partitions pada Aplikasi Seleksi Promosi Kenaikan Jabatan. Jurnal Teknologi Sistem Informasi dan Aplikasi, 2(4), 155-161.

Mustaqbal, M. S., Firdaus, R. F., \& Rahmadi, H. (2015). Pengujian Aplikasi Menggunakan Black Box Testing Boundary Value Analysis (Studi Kasus : Apilkasi Prediksi Kelulusan SNMPTN). Jurnal Ilmiah Teknologi Informasi Terapan, l(3), 31-36. doi:10.33197/jitter.vol1.iss3.2015.62

Rahayuda, I. S., \& Santiari, N. L. (2017). Basis Path Testing of Iterative Deepening Search and Held-Karp on Pathfinding Algorithm. Jurnal Ilmiah Kursor, 9(2), 39-48. doi:10.28961/kursor.v9i2.129

Simarmata, J. (2010). Rekayasa Perangkat Lunak. Yogyakarta: Andi.

Sukamto, R. A., \& Shalahuddin, M. (2013). Rekayasa Perangkat Lunak Terstruktur dan Berorientasi Objek. Bandung: Informatika.

Zuriati, Widyawati, D. K., Sitanggang, I. S., \& Buowo, A. (2018). Teknik Pengujian Boundary Value Analysis pada Aplikasi Learning Management System Polinela. Jurnal TAM (Technology Acceptance Model), 85-92. 